Sakharova O. M.*,

orcid.org/0000-0002-7391-7499

\title{
PHYSICAL EDUCATION AS PRESCHOOLERS' PHYSICAL DEVELOPMENT COMPONENT
}

The article considers philosophers' and teachers' scientific views on physical education and its impact on the personality's all-round development; and formation of physical education as a science. Plato's, Socrates's, and Horace's ideas of the importance of exercise and motor activity in different periods of people's life have been identified; J. Comenius's thoughts about the importance of properly selected, dosed physical exercises, their regularity in strengthening the children's health, about their important function in terms of spiritual and ethical education have been revealed. J. - J. Rousseau's thoughts on the importance of hardening of the body and senses and the formation of motor skills, moving games and daily walks in physical development; the idea of free upbringing of a comprehensively developed strong, skillful and intelligent personality have been given. J. Locke's ideas about physical education from the person's first days of life, about the study of refined manners, ballroom dancing, and other elements of gallantry, which externally distinguish "the noble" from the commoners, have been presented. Georges Demeny's thoughts on the importance of continuity of gymnastic exercises, the use of stretching exercises, relaxation, and movements to music have been revealed. The following ideas have been considered: the contribution to the theory of children's physical education of such doctors and progressive figures as E. Pokrovskyi and E. Dementiev; Georges Demeny's gymnastic system of physical education with continuous classes, use of stretching exercises, relaxation and movements to music; the close connection of the mental education process with physical exercises of K. Ushynskyi; P. Lesgaft's theory of physical education, based on the laws of harmony, gradualness and sequence of human development. The four groups of physical exercises and games by P. Lesgaft, and the idea of the folk games educational role have been proposed. The role of a teacher's word, addressed to the child's mind and including sample mechanical imitation, an inseparable link between mental education and physical exercises, has been stated.

Keywords: physical activity, physical development, all-round development, gymnastics, physical exercises, physical education, social education, hardening.

The statement of the issue. The foundations of health are known to be laid and the main features of a person's personality are known to be brought up in the preschool childhood. A family and preschool education institutions should create favorable conditions for children's optimal physical development, gaining knowledge about the human body, and mastering sanitary and hygienic skills. Children must gradually learn to be the creators of their bodies and health perfection. Good health is the key to children's development in other personal aspects. This feature is emphasized by the folk wisdom: "healthy mind lives in a healthy body". "There is no happiness without health", - says the Ukrainian proverb [6, p. 160-161].

Physical education has historically been one of the first pedagogical problems, which is considered by many educators and psychologists both in the historical and pedagogical heritage and in modern researches. It is historically one of the most ancient areas of the purposeful educational influence on the younger generation. The formation of the theory of physical education as a science notified the emergence of practice as a social phenomenon. With the emergence of culture and science, the complication of social relations between people in slave-owning states, the first systems of children's social education appeared, which necessarily provided for younger generations' all-round and physical development.

*C Sakharova O.M.

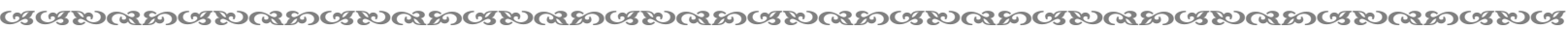


The analysis of relevant research. Modern theory and practice of physical education have been enriched by studies by O. Dubohai, S. Ikonnikov, T. Krutsevich, V. Maksakov, L. Matvieiev, K. Ohnista, A. Ohnista, V. Tsaryk, B. Shyian, etc., who study the influence of physical culture on the person's all-round development in various aspects. The researches of such scientists as T. Andriushchenko, I. Bekh, O. Bohinich, N. Denisenko, O. Kononko, V. Nesterenko deal with preschoolers' education and rehabilitation in the context of focusing on the child's personality. T. Andriushchenko, O. Bohinich, N. Levinets, L. Lokhvytska research creation of a health-preserving environment in preschool education, directions and optimal ways of using health-preserving technologies in the educational process of preschool education institutions.

The purpose of the article is to analyze pedagogical and philosophical views on physical education and its application in the pedagogical process of schools and other educational institutions.

The body of the research. The importance of exercise in children's health improvement is stressed in Socrates's, Plato's, Aristotle's and other scientists' philosophical judgments. They emphasize that people's physical activity at different periods of their lives replaces any medication. Plato (427-347 BC) said: "Gymnastics is a healing part of medicine". According to him, children's games should be directed in such a way that they get used to the adults' lifestyle from an early age. Along with motor games, they should gradually get used to exercises with jumping, ball, dancing to music, swimming, so that "because of body weakness they did not show cowardice during the war or in any other cases" [2, p. 34].

The famous philosopher of antiquity Plato (429-347 BC) wrote "... Then they send children to a gymnastics teacher, so as to better adapt their bodies to a courageous life and so that their physical weakness does not develop cowardice during war or in any other cases..." [7, p. 18]. It is worth mentioning that gymnastics teachers at that time not only taught certain exercises (e.g., wrestling), but also observed their impact on the body and keeping hygienic rules [7, p. 19]. "It is difficult to find something better than what was found in ancient times. For the body it is a gymnastic education, and for the soul it is a musical one" - said the scientist [5, p. 139].

As the ancient Greek poet Horace stated "If you do not run while being healthy, you will have to run when you get sick" [1, p. 4], thus indicating that exercise and motor activity are the best way to health.

The experience gained in the development of physical exercises and folk motor games during the early Middle Ages influenced outstanding educators from different countries (J. Comenius, J. - J. Rousseau, J. Pestalozzi and others) who while developing their pedagogical systems substantiated the importance of physical education in the younger generations' allround training.

The prominent Czech educator John Comenius (1592-1670) being under the influence of the views of the Renaissance utopians, and summarizing personal experience, came to the conclusion that it is necessary to use children's physical education in the school and family pedagogical process. Thus, in his works "Great Didactics" and "Mother's School", which also addressed the issues of preschool children's raising, it is noted that properly selected and dosed physical exercises strengthen children's health and increase their efficiency. He recommended that mothers should breastfeed their babies and let them, when they grow up a little, play and run more [2, p. 34-35]. John Comenius was convinced that person's formation should begin in early childhood. Everything learnt at this time is especially firm [7, p. 22]. Bold and completely new methods of education were already clearly seen in John Comenius's works. The basis of these methods was physical development, without which a person with good health is unthinkable [7, p. 23].

John Comenius paid great attention to the physical exercises system formation. Among the children's motor games, he singled out those that he found useful, supplementing them in accordance with the requirements of military training of the time with running, jumping,

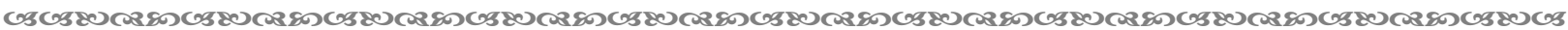


wrestling, swimming and getting a spear in the ring. The teacher recommended that the physical exercises be shown first so that they could be performed without any danger to life. In John Comenius's pedagogy the role of various games and physical exercises was not limited to physical training; they performed an important function in terms of spiritual and ethical education [1, p. 35].

The English philosopher and educator John Locke (1632-1704) spoke about the importance of physical education as part of children's all-round development. He declared that the weaker the body and the less will a person has, the less opportunity he has to achieve the goal. Therefore, he believed that physical education should begin from the first days of human life, considering it as the first adults' influence on children [7, p. 23]. The scientist recommended studying the refined manners, ballroom dancing, and other elements of gallantry, which externally distinguish "nobles" from commoners. In his opinion, all physical education should be carried out by competitive and game method [8, p. 16].

According to his theoretical concept of physical education, there was a characteristic attempt to justify the usefulness of physical exercises for the younger generation. First of all, in his opinion, a person needs to take care of good health, constantly take care of his body, exercise regularly, and have good manners and self-confidence. The popularity of J. Locke's theory contributed to the introduction of physical education in the form of motor games, sports and sports games into the educational institutions of England [2, p. 35].

The French teacher, philosopher and educator Jean-Jacques Rousseau (1712-1778) proved the idea of free education of an all-round developed strong, skilled and intelligent personality in his work "Emile, or about education". Thus, he believed that any social problem is related to the human evil, and the evil, in its turn, comes from human weakness. This situation can be changed only by educating a hardened and strong younger generation. The more a child learns to fight the forces of nature, the more agile and strong he grows [2, p. 35]. Jean J. Rousseau identified three stages in physical education: 1)hardening of the body; 2) hardening and development of the sense organs; 3) hardening, improvement of the sense organs and the formation of motor skills [8, p. 140].

J. - J. Rousseau expressed an opinion that did not coincide with that time opinions that a woman should be physically educated. So, the scientist was against the girl being indoors all the time, being deprived of fresh air, and offered to educate them, indulging them in motor games in the fresh air and daily walks. The scientist wrote "They should play, jump, run, shout, as it is typical of their age" $[7$, p. 23].

J. - J. Rousseau was the first who considered it necessary to train children's sense organs. In his pedagogical recommendations, he stressed the importance of the children's motor activity development, aimed at overcoming various natural obstacles, such as climbing trees, climbing over a wall, jumping, and swimming. J.- J. Rousseau followed other progressive teachers' views in his system. For example, he followed the principle of love for physical labor, for the systematic mobility of man, which should be inculcated in childhood as J. Locke did. He supported the views of John Comenius that physical education should begin from the first days of a child's birth. In his opinion children's motor games and exercise in the fresh air should be the basis of physical education [2, p. 35].

The famous Swiss educator J. Pestalozzi (1746-1827) in his work "Elementary Gymnastics" grouped the selected free exercises depending on the mobility of human joints (by anatomical classification), characterized the types of exercises depending on the mobility of the joints, by anatomical classification: exercises for head, legs, arms, and trunk. He considered these exercises as a "preparatory tool" for children's effective physical education, through which you can provide training for more complex movements, sports exercises, etc. [2, p. 36]. The scientist put forward the theory that a person is born with certain abilities inherent in it. According to him the purpose of education is only to develop these abilities through exercise. During his life, the scientist believed that a person could not acquire any makings if they were not laid in him at birth [7, p. 24].

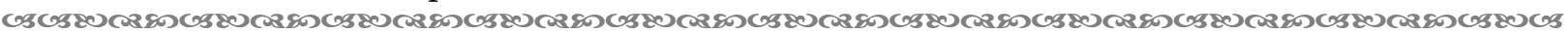


At the end of the XVIIIth century, the famous philosopher and educator of Ukraine H. Skovoroda (1722-1794) paid great attention to the issues of physical education. In his work "The Noble Erodii" the clearly substantiated is the position that children from the first years of life should receive physical education, which "will strengthen them in a way that will help to better understand the sciences" $[2$, p. 36].

Thus, teachers and philosophers of the XVII - XVIII centuries scientifically substantiated and actively promoted the need for personality's all-round development, which combines a broad education and physical perfection [2, p. 36].

The English philosopher and educator Robert Owen (1771-1858) wrote that "the primary task of a community will always be to provide all its members with the best physical, moral and mental education". He was convinced that health, physical perfection and mental education will bring true happiness to mankind [7, p. 27]. The French philosopher, sociologist Charles Fourier (1772-1837) also was of such an opinion. Thus, he argued, “... education aims to carry out the full development of physical and mental abilities ..." [7, p. 26].

The famous French physiologist and educator, author of the gymnastic system of physical education Georges Demeny (1850-1917) developed this system. It was aimed at continuous classes, the use of stretching exercises, relaxation, and movements to music. However, this system did not find much support due to the fact that young people were encouraged to military service, rather than to psychophysical improvement [7, p. 28].

A significant contribution to the theory of children's physical education was made by doctors and progressive figures E. Pokrovskyi (1838-1895) and E. Dementiev (1850-1919). E. Pokrovskyi wrote more than 70 works on physical education. In the book "Children's physical education in different nations, mainly Russia", he substantiates the position that the development of society general culture depends on the development of children's and youth's physical education. E. Dementiev is the author of the fundamental work "Gymnastics, or Games". Among the means of physical education, he put motor games, which are most useful for children, on the first place [2, p. 36-37].

The prominent teacher K. Ushynskyi (1824-187) believed that the process of mental education is closely related to physical exercises [7, p. 34]. Thus, according to K. Ushynskyi, it is necessary to use a rich arsenal of folk games, most accessible to children in physical education. K. Ushynskyi was convinced that games not only promote children's physical development, but also strengthen their health [6, p. 166].

A special place in the development of the physical education scientific foundations is occupied by the teachings of scientist-educator, doctor of medicine and surgery P. Lesgaft (1837-1909), author of the original, scientifically sound system [4, p. 33]. In his scientific activity a significant place is occupied by the development of issues of children's physical education, as evidenced by the subject of most of his scientific works (a total of 130) [3, p. 8].

In his fundamental work "The Guide to the School-Aged Children's Physical Education" he scientifically substantiated the concept of physical education. The main provisions of the physical education theory developed by P. Lesgaft (the idea of harmonious development; the need to be guided by didactic principles in teaching children physical exercises; methods of mastering the movements of their bodies in stages) are still relevant [2, p. 37].

P. Lesgaft's system of physical education is based on the laws of harmony, gradualness and sequence of human development. Peter Frantsovych considered the performance of physical exercises as the only simultaneous process of spiritual and physical improvement of a child. He emphasized the role of the teacher's word, addressed to the child's mind, which precludes mechanical imitation of the sample [4, p. 33]. Thus, the scientist emphasized that a physical education teacher should wield "a word much better than a literature teacher" [7, p. 35]

He based the proposed system on didactic principles, in particular consciousness, in the performance of physical exercises, without diminishing the role of others. P. Lesgaft 
recommended taking into account children's age, gender and individual characteristics in the process of physical education.

P. Lesgaft's system of physical education was aimed at the personality's all-round development. Physical exercises, having a material (physical) and spiritual (ideal) side, in addition to education, were aimed at physical development, improvement of strength, endurance, speed, and agility.

Based on the scientific achievements of anatomy, physiology, anthropology, P. Lesgaft proposed such a classification of physical exercises (motor actions) and games, which consisted of four sections (groups) [3, p. 9].

The first group includes simple movements used in junior classes to teach a child to control his body (movements of the head, trunk, limbs), and complex, such as walking, running, and throwing. The movements are performed by the children after the explanation, without being shown. Thus, according to P. Lesgaft, their conscious implementation is achieved [3, p. 9-10].

The second group includes exercises with a gradual increase in effort ("with increasing stress"), which are used in the middle grades, where children learn to overcome ever-increasing difficulties and new more complex obstacles (exercises with sticks, dumbbells, throwing iron or wooden balls, jumping, wrestling, climbing, etc.). The weight of objects for throwing gradually increases, the time of overcoming the distance when walking or running decreases, the distance is lengthened.

The third group presents motor actions related to orientation in space or time ("study of spatial relations"), used in senior classes. They are throwing at the aim, running at a given pace, jumping a certain distance, and so on.

The fourth group was formed by P. Lesgaft's "systematic exercises in the form of complex actions": these are various games, swimming, walks, hikes, excursions, skating, skiing, and fencing, which are used in all classes together with the previously mentioned activities [3, p. 10]. The scientist pointed out: "Everything that is learned in systematic classes is used in games, so all the movements and actions produced here must fully correspond to the strength and skill of those who are engaged and conducted with the greatest possible accuracy and dexterity" [4, p. 136].

The scientist believed that physical education should last a lifetime, so it is important from childhood to teach a child to consciously learn physical exercises, be able to rationally, i.e. with the least effort, but with the greatest effect, use them [7, p. 34].

P. Lesgaft paid special attention to the use of folk games, emphasizing their important educational role. In games, he said, children reproduce what they see. Therefore, he recommended them to spend more time outdoors in games and exercises [3, p. 10].

P. Lesgaft's theory became a solid foundation for the further development of the science of physical education of children, in particular those of a preschool age [3, p. 11].

The pedagogical process should be based on knowledge of the child's physiology and psychology. A teacher, who does not know these disciplines, cannot properly carry out the complex process of education [7, p. 33]. And the process of mental education was seen by him in inseparable connection with physical exercises. Thus, in his opinion, physical exercises should be in every lesson, then mental activity will be more effective [7, p. 34]. We should point out that the teacher has repeatedly emphasized that in physical education it is necessary to use a rich arsenal of folk games, most accessible to children. He was convinced that games not only promote children's physical development, but also strengthen their health [2, p. 37]. Thus, in folk games, he pointed out, "the child learns to think, acquires important knowledge..." [6, p. 359].

Conclusions. Thus, the scientific and methodological literature analysis has shown that physical education is the basis of all-round personal development and is historically one of the most ancient areas of purposeful educational influence on the younger generation. Scientific achievements of philosophers, psychologists, and teachers show that physical

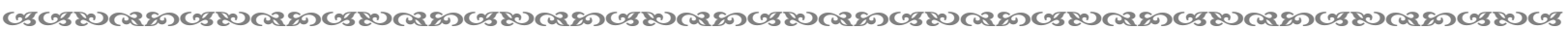


education is one of the prerequisites for the effectiveness of preschool children's mental, moral, and aesthetic education and the appropriate level of preschoolers' general development allows them to approach physical and mental perfection. Thus, physical education, as preschool children's physical development component, effectively affects not only the development of children's physical qualities but also is the basis of their all-round development.

Perspectives of our following research will be aimed at studying the use of innovative technologies in the process of older preschool children's physical education.

\section{Bibliography:}

1. Дубогай О. Фізкультура як складова здоров'я та успішного навчання дитини. Київ: Шкільний світ: Вид. А. Галіцина. 2006, 128 с.

2. Вільчковський Е. С., Курок О. І. Теорія і методика фізичного виховання дітей дошкільного віку: навч. посіб. Суми: ВТД «Університетська книга», 2005. 428 с.

3. Загородня $\Lambda$. П., Тітаренко С. А., Барсуковська Г. П. Фізичне виховання дітей дошкільного віку: навчальний посібник. Суми: Університетська книга, 2011. 22 с.

4. Кенеман А. А., Хухлаева Д. В. Теория и методика физического воспитания детей дошкольного возраста: учеб. пособие дия студентов пед. ин-тов по спец. «Дошкодьная педагогика и психология». Москва: Просвещение, 1978. 272 с.

5. Платон. Собрание починений: в 4 т. Т. 1.: пер. с древнегреч. / общ. ред. А. Ф. Аосева, В. Ф. Асмуса, А. А. Тахо-Годи. Москва : Мысль, 1994. 654 с.

6. Поніманська Т. І. Дошкільна педагогіка: навчальний посібник для студентів вищих навчальних закладів. Київ: Академвидав, 2008. 456 с.

7. Степаненкова Э. Я. Теория и методика физического воспитания и развития ребенка: учеб. пособие для студ. высш. пед. учеб. заведений. Москва: Академия, 2001. 368 с.

8. Худолій О. М. Загальні основи теорії і методики фізичного виховання: навч. посібник. 2-е вид. випр. Харків: ОВС. 2008. 406 с.

\section{Reference:}

1. Dubohai, O. (2006). Fizkultura yak skladova zdorovia ta uspishnoho navchannia dytyny [Physical education as a component of health and successful learning of a child]. Kyiv: Shkilnyi svit: Vyd. L. Halitsyna [in Ukrainian].

2. Vilchkovskyi, E. S., \& Kurok, O. I. (2005). Teoriia i metodyka fizychnoho vykhovannia ditei doshkilnoho viku [Theory and methods of preschool children's physical education]. Sumy: VTD "Universytetska knyha" [in Ukrainian].

3. Zahorodnia, L. P., Titarenko, S. A., \& Barsukovska, H. P. (2011). Fizychne vykhovannia ditei doshkilnoho viku [Physical education of preschool children]. Sumy: Universytetska knyha [in Ukrainian].

4. Keneman, A. A., \& Khukhlaeva, D. V. (1978). Teoriia i metodika fizicheskogo vospitaniia detei doshkolnogo vozrasta [Theory and methods of physical education of preschool children]. Moskva: Prosveshchenie [in Russian].

5. Platon (1994). Sobranie sochineniy v 4 t. T. 1 [Collection of works in 4 vols. Vol. 1]. (A. F. Loseva, V. F. Asmusa, \& A. A. Takho-Godi, Trans.). Moskva: Mysl [in Russian].

6. Ponimanska, T. I. (2008). Doshkilna pedahohika: navchalnyi posibnyk dlia studentiv vyshchykh navchalnykh zakladiv [Preschool pedagogy: a textbook for students of higher educational institutions]. Kyiv: Akademvydav [in Ukrainian].

7. Stepanenkova, E. Ya. (2001). Teoriia i metodika fizicheskogo vospitaniia i razvitiia rebenka [Theory and methods of physical education and development of a child]. Moskva: Akademiia [in Russian].

8. Khudolii, O. M. (2008). Zahalni osnovy teorii i metodyky fizychnoho vykhovannia [General principles of theory and methods of physical education: textbook. manual]. Kharkiv: OVS [in Ukrainian]. 


\section{ФІЗИЧНЕ ВИХОВАННЯ ЯК СКЛАДОВА ФІЗИЧНОГО РОЗВИТКУ ДІТЕЙ ДОШКІЛЬНОГО ВІКУ} orcid.org/0000-0002-7391-7499

У статті розглядаються наукові погляди філософів і педагогів на фізичне виховання та його вплив на всебічний розвиток особистості; становлення фізичного виховання як науки. Розкриваються думки Платона, Сократа, Горація про значення занять фізичними вправами, рухову активність людини у різні періоди ї життя; Я. Коменського про значення правильно дібраних, дозованих фізичних вправ, їх систематичність у зміцненні здоров'я дитини, про їх важливу функціюо з точки зору духовного й етичного виховання; думки Ж. - Ж. Руссо про значення загартування тіла, органів чуття та формування рухових умінь і навичок, рухливих ігор та щцоенних прогулянок у фізичному розвитку; ідея вільного виховання всебічно розвиненої сильної, вмілої та розумної особистості. Подаються ідеї Дж. Аокка про фізичне виховання зперших днів життя людини, про вивчення витончених манер, бальних танців, інших елементів галантності, котрі зовні вирізняють «знатних» від простолюдинів. Розкриваються думки Жоржа Демені про значення безперервності занять гімнастичними вправами, використання вправ на розтяжку, розслаблення, рухи під музику. Розглядається внесок утеорію фізичного виховання дітей лікарів та прогресивних діячів Є. Покровського та Е. Дементьева; гімнастична система фізичного виховання Жоржа Демені з безперервними заняттяли, використанням вправ на розтяжку, розслаблення та рухи під музику; тісний зв'язок процесу розумового виховання з фізичними вправами К. Ушинського; теорія фізичного виховання П. Аесгафта, що ьрунтуеться на законах гармонії, поступовості й послідовності розвитку людини. Пропонується чотири групи фізичних вправ та ігор П. Аесгафта, ідея виховної ролі народних ігор. Говориться про роль слова педагога, зверненого до свідомості дитини, що виключае механічне наслідування показаного зразка, нерозривний зв'язок розумового виховання з фізичними вправами.

Ключові слова: рухова активність, фізичний розвиток, всебічний розвиток, гімнастика, фізичні вправи, фізичне виховання, суспільне виховання, загартування.

Дата надходження статті: 15.12.2020 p. Рецензент: доктор педагогічних наук, професор Степанова Т. М.

УДК 37.04

DOI https://doi.org/10.37915/pa.vi47.180

Цюпак I. М.*,

orcid.org/0000-0002-7427-8588

\section{ТЕХНОЯОГІЯ ТЬЮТОРСЬКОГО СУПРОВОДУ ДІТЕЙ ДОШКІЛЬНОГО ВІКУ}

У статті обьрунтовано спеццифіку тьюторського супроводу як технологї, орієнтованої назабезпечення умов виявлення, побудови й реалізації індивідуальної траєкторії розвитку дитини дошкільного віку. Наукові пошуки з проблеми дослідження здійснено з усвідомленням потреби модернізації дошкільної освіти, адже дієві засоби такої роботи не можуть бути знайдені, поки вихователь працһюе тільки в традиційній освітній парадигмі «посередника», що забезпечуе передачу від дорослих до дітей певного соцізального досвіду, норм поведінки й ділльності.

Авторкою зроблено припущення щзодо використання більш продуктивного підходу, а саме тьюторського, при якому вихователь виступае у ролі «довіреної особи» дитини дошкільного віку й через тьюторський супровід забезпечує становлення суб'єктності, відповідальності

*C Цюпак I. M.

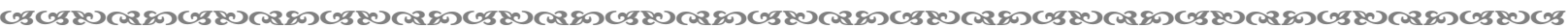

